81'1:165

811.163.41'37

811.163.41'373.6

https://doi.org/10.18485/kij.2020.67.2.2

ВАЛЕНТИНА М. ИЛИЪ*

Оригинални научни рад

Универзитет у Београду

Примљен: 07.12.2020.

Филолошки факултет

Прихваћен: 14.12.2020.

\title{
АПСТРАКТУМИ ИСТИНА И ЛАЖ У САВРЕМЕНОМ СРПСКОМ ЈЕЗИКУ: КОНЦЕПТУАЛИЗАЦИЈА ИСТИНЕ (когнитивнолингвистички приступ) ${ }^{* *}$
}

\begin{abstract}
Рад представља први део истраживања у коме су апстрактне именице истина и лаж, које обележавају важну сферу човековог духовног живота, анализиране когнитивнолингвистичким методом концептуалне анализе на корпусу савременог српског језика. Пре саме анализе описана је природа апстрактума, а затим је представљена етимологија истине и лажи, која показује рудиментарно разумевање ових појмова у свести наших предака, као и њихова семантика у речницима савременог српског језика. У главном делу рада даје се преглед и анализа одабране грађе, којом се долази до појмовних метафора и сценарија груписаних по различитим нивоима општости, који илуструју концептуализацију истинЕ у савременом српском језику. На самом крају изводи се закључак и издвајају се кључне карактеристике обликовања овог појма у нашем когнитивном систему. У наредном раду биће представљен други део истраживања - концепт лАжи и изведен закључак о заједничким обележјима концепата ових именичких антонима.
\end{abstract}

Кључне речи: ИСтинА, лАЖ, апстрактум, когнитивна лингвистика, конщептуална анализа, појмовна метафора, конщепт.

*valentina.ilic@fil.bg.ac.rs

* Рад представља скраћену верзију првог дела мастер рада Кониептуализаиија апстрактних именица истина $и$ лаж у савременом српском језику, који је одбрањен 30. септембра 2015. године (Комисија: проф. др Рајна Драгићевић (ментор) и проф. др Драгана Вељковић Станковић). Да ову анализу спроводимо данас, она би, разуме се, била обогаћена новим теоријским погледима и приступима. Потрудили смо се, ипак, да у овом тексту задржимо садржај, структуру и методологију мастер рада и да на тај начин прикажемо његове аутентичне резултате. Овом приликом се објављује концептуализација истине, а другом делу, у следећем раду, биће објављена концептуализација лАжи. Рад је урађен у оквиру пројекта Српски језик и његови ресурси: теорија, опис и примене (178006), који финансира Министарство просвете, науке и технолошког развоја Републике Србије. 


\section{1. Увод}

1.1. Када је реч о типовима именица с обзиром на степен њихове конкретности, у науци о језику могу се издвојити три типа: оне које означавају конкретне појмове (кyћa, nac, књига), оне које представљају неки осет или осећање (топлота, радост), те оне које означавају појмове који постоје само на нивоу мисаоног представљања (грех, истина, живот). Именице из друге и треће групе називају се апстрактним именицама у најширем смислу (Черњејко 1997: 197). Они у речи добијају свој „лик”, а језик, као огледало људских мисли, показује како о њима мислимо и како их разумевамо.

Будући да припадају сфери духа, апстрактне именице погодно је анализирати семантичким методом који почива управо на структури мишљења и поимању стварности. Такав је, данас у науци о језику добро познат, метод концептуалне анализе, поникао на темељима когнитивне лингвистике, којим долазимо до начина поимања различитих непредметних појава. Заправо, читав апстрактни и духовни живот човек саображава познатим појмовима који га окружују и на тај начин им у мислима даје конкретни, предметни лик. Према Ф. Буслајеву, „сваки предмет постоји за човека само онда када га он спозна, када уђе у његову мисао и изрази се речју" ( $\left.{ }^{2} 1867: 316\right)$.

1.2. Концептуални метод за анализу апстрактума адекватнији је од других семантичких метода (компоненцијалног, на пример), будући да одговара њиховој семантичкој природи - они су само умно спознатљиви, а границе међу њиховим значењима нису јасне, већ флуидне и неодређене. Концептуалном анализом у когнитивној лингвистици долази се до појмовних метафора, које представљају начин разумевања једног апстрактног појма (А) помоћу другог конкретног (Б), међу којима постоји читав низ системских кореспонденција. Њихово реализовање познато је као пресликавање (енгл. mappings), при чему се структура конкретног појма (тзв. изворног домена) пресликава на апстрактни, непознат појам (тзв. циљни домен) (исп. нпр. Лејкоф и Џонсон 1980; Унгерер и Шмид 1996; Кликовац 2004; Еванс и Грин 2006; Гентнер и Баудл 2008; Кевечеш ${ }^{2} 2010$; Драгићевић ${ }^{2} 2010$ и др.). Важна особина појмовних метафора јесте једностраност (Лејкоф и Џонсон 1980: 10): нека појмовна метафора ће осветлити (енгл. highlighting) само један аспекат датог појма, док ће остали остати прикривени (енгл. hiding). Усмеравање на један аспекат концепта не открива његове друге аспекте. Отуда се за разумевање неког појма користи више метафора (тзв. метафорички плурализам) (Лејкоф и Џонсон 1999: 60-73), које не морају бити међусобно конзистентне и које могу припадати различитим нивоима општости. Тако се издвајају метафоре са генеричког нивоа, које су на врху скале општости, и метафоре са специфичног нивоа, које су конкретније и смештају се ниже на вертикалној скали апстрактно-конкретно. Примарне, фундаменталне појмовне метафоре могу се развијати и стварати комплексне метафоре у којима су усађена знања и веровања једне културе (Лејкоф и Џонсон 1999: 60). Оне се даље могу груписати и представљати читав метафорички сценарио који сликовито у струк- 
тури тзв. домена, фрејма или схеме показује разумевање неког појма или појаве (Унгерер и Шмид 1996: 127; Драгићевић ${ }^{2} 2010: 93$ ).

Отуда метафоре умногоме олакшавају разумевање света који нас окружује и наше делање у њему, а њој је доста пажње посвећено и у филозофској литератури. „Метафора је интелектуални поступак којим успевамо да схватимо оно што се налази изван наше моћи поимања. Преко онога што нам је најближе и чиме најбоље владамо, можемо да постигнемо мисаони контакт са оним далеким и неприступачнијим [...] Без ње би на нашем менталном хоризонту постојала дивља област која би, у начелу, била под нашом влашћу, али би у ствари остала непозната и неукроћена" (Ортега и Гасет 2010: 215).

\section{2. Предмет, корпус, методологија и циљеви истраживања}

2.1. У овом истраживању бавили смо се семантичком анализом појмова означених именицама истина и лаж. Њих је Љ. Черњејко издвојила, поред добра и зла, и лепог и ружног, као једну од трију главних дихотомија човековог духовног живота, које сачињавају три сфере духа: етику, естетику и логику, и које се одражавају кроз морал, уметност и науку (1997: 8). С обзиром на њихову апстрактну семантичку природу, анализирани су из угла когнитивнолингвистичког приступа, уз примену концептуалне методе. На основу конкретних примера покушали смо да дођемо до што већег броја појмовних метафора које илуструју концептуализацију истинЕ и лАжи у савременом српском језику, као и да утврдимо да ли се поједине појмовне метафоре групишу чинећи тако метафорички сценарио, те какав је однос међу њима на скали специфичност-генеричност, односно конкретност-апстрактност.

2.2. Корпус за анализу чине Речник српскохрватског књижевног и народног језика Српске академије наука и уметности (РСАНУ), Речник српскохрватскога књижевног језика Матице српске (РМC), Речник српскога језика Матице српске (РСЈ), речници синонима М. Лалевића и П. Ћосића, Асоцијативни речник српског језика, Обратни асоцијативни речник и Корпус савременог српског језика Д. Витаса (електронски корпус, скраћено: ЕКор). У случају РСАНУ, РМС, PCJ и речника синонима, испитивани су примери који се налазе у оквиру одредница истина и лаж, као и примери који потврђују њихове деривате. У Асоцијативном речнику посматране су реакције на стимулусе истина и лаж, а у електронском корпусу претраживан је ,анотирани корпус са изворима $(2013, \sim 122$ милиона речи)" и у оквиру њега сви примери у којима би се ове две именице јавиле у било ком падежном облику, као и њихови деривати и кључни синоними (у основном облику). Као резултат претраге, Корпус је приказао више од десет хиљада конкорданци.

2.3. Анализа примера из речника и електронског корпуса подразумева увид у минимални контекст у коме се дата лексема реализује, на основу чега је утврђивана појмовна метафора која описује разумевање истинЕ/лАжи. Анализиране су 
и семантика деривата ових именица, као и значења синонима. Све појмовне метафоре затим су класификоване тако да се полази од најопштијих, генеричких, које се даље гранају и конкретизују кроз низ специфичнијих метафора. Неке од њих груписане су и тако чине метафоричке сценарије, док су неке потпуно јединствене и(ли) засноване на идиосинкратичким примерима. У тексту овог истраживања доносимо главне резултате анализе, најпре оне која се тиче концепта истинЕ, а затим оне која се односи на концепт лАжи.

2.4. Ово истраживање имало је циљ да на широком корпусу савременог српског језика покаже начин на који се поимају истинА и лАж, појмови који се у већини граматика, лексикологија и уџбеника наводе као примери праве антонимије. Питања која су се пре истраживања могла поставити јесу: Да ли су концепти истинЕ и лАжи можда подударни или се разликују? Ако се разликују - да ли су те разлике у некој вези са нивоом општости појмовних метафора? Да ли су чињенице о антонимима које се тичу семантичког саодношења и разликовања једне семе у неком симетричном односу са појмовним метафорама које описују концепте ових појмова? Најзад, да ли је овде реч о правим антонимима? Још један од разлога семантичког испитивања управо ових именица јесте чињеница да су оне једна од фундаменталних антиномија човековог духовног живота. О њима се писало још од античких времена, биле су предмет интересовања највећих мислилаца у историји филозофије (исп. нпр. Шкембер 2012), а и данас се истражују у оквирима различитих интердисциплинарних приступа (в. Ван Дитмарх и др. 2020: 466-484).

2.5. Ограниченост простора спречава нас да у једном раду представимо описано истраживање у целости, па је из тог разлога оно подељено у два дела. У овом, првом, представљен је Увод и концепт истинЕ, а у следећем раду биће представљен концепт лАжи и Закључак. Јасно је да се нису могли наводити сви примери из грађе. Овде се дају тек понеки, довољни да потврде одређену појмовну метафору.

\section{3. Истина и лаж - етимологија и значења у речницима савременог језика}

3.1. Ако разумемо и прихватимо ставове појединих когнитивних семантичара о утицају историјског значења речи на њену савремену значењску структуру и обликовање појмова, што чак „ни Сосир нити било ко од његових колега не би порекао" (Свитсер 1990: 1-16), намеће се питање етимологије ових именица, која указује на рудиментарне карактеристике концепата који се рефлектују, у већој или мањој мери, на данашње разумевање датих појмова.

3.2. У Etimologijskom rječniku Петра Скока именицу истина проналазимо у оквиру одреднице $и с т и$, за коју аутор наводи да је била придев, а данас је то „заменица идентитета", која појачава идентификацију показних заменица maj, oвaj, онај, он. Именица истина настала је додавањем суфикса -ина на поменуту осно- 
ву; еквивалент у латинском јој је veritas, а постоји и негирани облик: неистина. Од ове именице настаје прилог уистину = ваистину, а придеви и нека поименичења која постоје у језику се не говоре: истинан, неистин; истиност, истиноћа, док су други у активној употреби: истинит, неистинит; истинитост. Глаголи истинити, -им (се) и истиновати, -ујем такође се не употребљавају; први се јавља са префиксом об-: обистинити, -им (се). Скок за најприхватљивије тумачење порекла значења узима следеће: $i s-t i$ се изводи од индоевропског корена *es- > jesam (1971). Дакле, истина је оно што јесте, што постоји. ${ }^{1}$

Наведена етимологија показује пут формирања појма истине, који иде од конкретног до апстрактног. Односно од заменице којом упућујемо на нешто конкретно, познато, у нашој близини, гради се апстрактум суфиксом -ина, који ће означити стварност, оно што јесте, али који ипак разумевамо посредством чулно спознатљивих, опредмећених појмова. Ово је еклатантан пример развоја лексичког система, који се углавном богатио оваквим, логичним, следом, од познатог и блиског ка непознатом и апстрактном. Ипак, у њеним значењима у појединим словенским језицима, како се наводи у ЕССЯ (в. фн. 1), примећује се задржавање означавања материјалног добра - новца, готовине, док ће употреба ове лексеме у примарном значењу у српском језику (а претпоставља се и у већини наведених језика) показати њено словенско примарно разумевање у виду ЕНТИТЕТА, односно ПРЕДМЕТА са јасним границама, на који можемо јасно указати (в. т. 4.1.3). ${ }^{2}$

3.3. Порекло именице лаж се у етимолошким изворима наводи уз доста ограда, могућих тумачења и претпоставки. У речнику П. Скока проналазимо је у оквиру одреднице лагати, која потиче од прасловенског корена *hg-, према ие. *leugh-, а чија паралела у латинском гласи mentiri. Поред бројних изведеница, посебно се издвајају „,апстрактуми”: лаж, лашка, лаштво, лагарија, лагање, лажиторба, лажи- (префикс у значењу „псеудо-”: лажибискуп, лажицар). Именица лаж има и варијанту лажа, где је глас $a$ настао од полугласника -ъ. То

${ }^{1}$ У Етимолошком речнику словенских језика (ЕССЯ) такође се наводи да је истина изведена од „придева" исти (*jbcтъjb), за чије порекло и значење се као највероватније узима тумачење В. Н. Топорова: ‘тај, управо тај’ у споју са значењем заменичке конструкције *is-to, која је идентична латинском iste, ista, istud 'овај, тај, управо овај, управо такав' (ЕССЯ 1974, том 8 [1981]: *xa-*jbvblga). У оквиру одреднице истина у овом речнику проналазимо податке да се она у неким словенским језицима (словеначком, чешком, пољском, руском, украјинском) и њиховим дијалектима употребљава и у значењу готовине, капитала, новиа (ibid.).

2 Занимљиво би било истражити ове концепте у другим индоевропским језицима. Већ на основу етимологије може се назрети њихово другачије разумевање. У романским језицима, од латинског veritas (< пие. *wērz-o-, који значи 'тачан, поуздан, веродостојан'), показује се да је истина пре свега оно у ШТА ВЕРУЈЕмо, док је, на пример, у енглеском (truth), или балтичким језицима, у њеном корену пие. *dreu-, које значи ‘чврст, постојан’ и које је било специјализовано за значење дрвета (енгл. tree, срп. дрво). У енглеском језику, на пример, на ову основу додат суфикс -th, настао од протогерманског суфикса *-itho (< пие. *-ita) за деривацију апстрактних именица (исп. нпр. depth, strenght, truth). У језицима са овим кореном за значење истине показује се њено разумевање као ЕнтитЕТА, односно чвРСТОГ ПРЕДМЕТА, Што овај концепт приближава словенском етимолошком концепту истиНЕ (в. т. 3.2) (ЕССЯ 1974, том 5 [1978]: *dělo_*dbržblb; OEP - Online Etymology Dictionary). 
видимо и из: ожујак, ген. ожујка (лажак, март), где је о настао из < *loiuj (-иј је овде придевски суфикс, уп. вол-уј-ски), а тај придев је поименичен суфиксом -bko. Скок овде додаје да је месец март назван тако због несталног времена (1972).

У ЕССЯ се уз одредницу *lъžb упућује на глагол *løgati, у оквиру кога налазимо опсежну елаборацију порекла ове речи и њених веза са другим језицима. Она је сродна са германским облицима (нем. lügen, шв. ljuga, англос. lyge, енгл. (to) lie; нем. leugnen 'одрицати, не признавати, негирати'). Ипак, овај облик није германизам, већ потиче од ие. *leugh-, што, како смо видели, наводи и П. Скок. Реч је, дакле, о германско-словенској лексичкој паралели, за коју је мало вероватна веза са балтичким језицима, која би семантику овог глагола довела у везу са лит. liugnas 'мочвара, бара' (ЕССЯ 1974, том 16 [1990]: *lokadlo_*lbživbcb; том 17 [1990]: *lъ̌̌b-*matješbnъjb). ${ }^{3}$ У ОЕР ће се експлицитно навести да је глагол to lie, од кога је настало поименичење, заправо реч непоуздане етимологије, а то нас спречава да изведемо закључак о основним карактеристикама њеног концепта. ${ }^{4}$

3.4. Треба запазити, на крају, да је лексема истина апстрактум од кога се изведени глагол (истинити) не употребљава, док је апстрактна именица лаж секундарна, изведена од глагола лагати.

\begin{tabular}{|cc|c|}
\hline I & II \\
\hline истина $\longrightarrow$ *истинити \\
\hline лагати $\longrightarrow$ лаж \\
\hline
\end{tabular}

Већ одавде се може закључити да истинА примарно постоји као датост, изван наше воље и активности, док је лАж искључиво производ људског деловања, односно свесног извртања истине.

Најзад, занимљива је чињеница да је сама етимологија истине транспарентна, јасна и неупитна, док је порекло лажи, односно глагола лагати магловито, мутно и у самој науци још увек непрецизно одређено.

3.5. Значења ових именица у савременом језику потражићемо у РМС и РСАНУ. Она су у њима представљена на следећи начин:

\footnotetext{
${ }^{3}$ Наводећи облике који потврђују индоевропске корене у албанском језику, В. Станишић, следећи К. Воткинса, помиње управо корен *leu-g $g^{h}$-, који значи 'прати' и коме одговарају бројни балтословенски облици у значењу 'глиб', 'пихтије', ‘бљузгавица', али и сличнозначне германске паралеле (енгл. lye ‘цеђ’) (Станишић 2012: 207). Остаје питање да ли су посреди два корена без значењске везе или су значења *leugh- ‘лагати' и *leu-g ${ }^{h}$ - ‘прати' ипак сродна.

${ }^{4}$ Знатно је једноставније разумети концепт појма означеног глаголом лагати у романским језицима, будући да је лат. mentiri настало од пие. корена *mend-, чије је значење поуздано: 'физички недостатак, грешка'. Дакле, семантика глагола развила се од физичког изгледа са недостатком, грешком, до апстраховања: 'исказивање онога што је погрешно' (ОЕР). У основи разумевања овога појма у романским језицима је, дакле, нетачност, нестварност, неоригиналност.
} 


\begin{tabular}{|c|c|}
\hline PMC (1967) & РСАНУ (1973) \\
\hline $\begin{array}{l}\text { йстина ж 1. оно што одговара ствар- } \\
\text { ности, што је у складу са збиьом, } \\
\text { стварно стање ствари; тврђење, } \\
\text { саопштење у којем се неки догађај } \\
\text { или нека ствар износе онакви ка- } \\
\text { ки су; супр. лаж. 2. морални идеал, } \\
\text { правда, правичност. 3. фил. поуздано } \\
\text { знање које правилно одражава ствар- } \\
\text { ност у свести и сазнағу човека. }\end{array}$ & $\begin{array}{l}\text { йстина ж (понекад појачано атри- } \\
\text { бутима: сушта, цела, жива, гола, } \\
\text { истинска и др.) 1. оно што одговара } \\
\text { постојећим чињеницама, стварно- } \\
\text { сти. 2. чињеница у коју се, као експе- } \\
\text { риментално, научно доказиву, може } \\
\text { веровати, или која коригује ранија } \\
\text { увереља. 3. високи морални прин- } \\
\text { цци, идеал, високо морално добро, } \\
\text { правда, поштење. 4. истинитост, } \\
\text { веродостојност, тачност. 5. покр. } \\
\text { оно ито је право, непатворено. }\end{array}$ \\
\hline
\end{tabular}

3.5.1. Из трију значења именице истина наведених у РМС можемо закључити да је основно значење у складу са наведеном етимологијом: истина је оно што јесте, што постоји, што одговара стварности, односно само тврђење које о томе говори. Њен прави антоним је лаж, обележен квалификатором супр. Секундарно значење тиче се домена моралности и правде, односно оно што је истинито, то је праведно и томе треба тежити (морални идеал). И најзад, истина се наводи као филозофска категорија, где је уопштено схваћена као знање (тј. истина је у нама). Речник САНУ ће ове семантичке реализације навести готово идентичним редоследом, с тим да у њему проналазимо и синониме, дате под бројем 4, који упућују на датост у коју се може веровати, али и покрајинско значење које се односи на оно што је неискварено, изворно, право. Занимљиво је да се у РСАНУ не јавља 3. значење из РМС, које се односи на поуздано знање, мада се оно можда може разумети као саставни део дефиниције под 2 у РСАНУ.

\begin{tabular}{|c|c|}
\hline PMC (1969) & РСАНУ (1981) \\
\hline $\begin{array}{l}\text { лаิж, лӓжи ж свесно изречена не- } \\
\text { истина, намерно извртање чиње- } \\
\text { ница; неистина уопште, обмана. }\end{array}$ & $\begin{array}{l}\text { лаิж, лӓжи ж намерно, свесно из- } \\
\text { нета нетачност, неистина; из- } \\
\text { мишљотина; превара, обмана. }\end{array}$ \\
\hline
\end{tabular}

3.5.2. Из наведеног значења другог члана антонимског пара у РМС јасно се закључује да лаж садржи и једну додатну, интенционалну сему: она је свесно изречена (Мршевић-Радовић 2008а: 48). Видимо да се лаж доживљава као исказ који не одговара стварности и који се изриче свесно, а потом и као неистина уопште, те обмана. Понуђена два синонима захтевају додатни коментар. Чини се да истокоренски антоним, неистина, не мора имати a priori интенционалну сему, он може значити $u$ све оно што није у складу са збиљом, а што се не мора свесно 
изрицати. Могућност тога значења наглашена је прилогом уопште. Такође, ова варијанта се користи и као еуфемизам за лексему лаж. Синоним обмана, као и лаж, има нечег од „свесно учињеног”, што јасно видимо из њеног примарног значења: 1. подвала, превара, лаж (РМС 1969; подвлачење је наше - В. И.). У полисемантичкој структури лексеме лаж у РСАНУ изостаје њено тумачење као неистина уопште. У њој је интенционална сема експлицитнија (в. намерно) и поткрепљена додатним синонимом: превара.

3.5.3. Колико год наведене дефиниције истине и лажи у двама дескриптивним једнојезичним речницима наоко биле сличне, анализа минималних разлика у њиховој лексикографској обради показује да се аутори ових речника не слажу око њиховог семантичког односа. Наиме, у првом објављеном, РМС, ове две именице стоје (одн. могу стајати) у односу праве антонимије, док су у касније објављеном тому РСАНУ оне у односу неправе антонимије. За лексикографе РСАНУ значење интенционалности нераскидиво је скопчано са лексемом лаж и она не значи и неистину уопште, а та чињеница онемогућава њихово сврставање у праве антониме. Овај закључак подржава и изостављање квалификатора супр. (лаж) из полисемантичке структуре именице истина у РСАНУ, чиме се истиче уочена семантичка неравнотежа међу члановима овог антонимског пара и одсуство праве супротности међу њима.

Одавде је јасније због чега ће бити занимљиво истражити их концептуалном методом и упоредити њихове базичне концепте у савременом српском језику. ${ }^{5}$

\section{4. Концептуализација истинЕ - преглед и анализа грађе}

4.1. Анализом описаног корпуса долази се до шездесетак појмовних метафора које описују концепт истинЕ и које припадају различитим нивоима општости. На најопштијем нивоу концептуализације издвајају се две метафоре, које се према класификацији Лејкофа и Џонсона, могу сматрати онтолошким (1980: 25-29): I) ИСТИНА ЈЕ ЕНтИтЕТ и II) ИСТИНА ЈЕ ПОЈАВА. Ове Две метафоре потврђује велики број примера, а они истовремено показују друге, специфичније метафоре, које су конкретизација наведених.

4.1.1. ИСТИНА ЈЕ ЕНТИТЕТ КОЈИ ЈЕ САКРИВЕН (Пр. Истрага је текЛа По свим правилима проналажења материјалне истине (РСАНУ) ${ }^{6}$; ...кад је важна исти-

\footnotetext{
${ }^{5}$ Развојем концепата истинЕ и лАжи кроз време, од 19. до 21. века, бавили су се у једном раду С. Новокмет и С. Слијепчевић (2012: 165-173). Њихов циљ је био да сагледају развој ових појмова и усложњавање метафора којима се они концептуализују у распону од једног и по века. Ми ћемо у овом истраживању, заснованом на знатно ширем корпусу, потврдити њихове закључке и доћи до већег броја метафора и метафоричних сценарија који обогаћују структуру и садржај датих појмова, као и њихов међусобни однос.

${ }^{6}$ Ознака речника (РСАНУ, РМС, РСЈ) подразумева да је пример у њима пронађен под одредницом истина/лаж, евентуално под одредницом која је њихов дериват, а који се јавља у примеру. Ознака „ЕКор” означава да је пример преузет из Корпуса савременог српског језика Д. Витаса. Уколико је пример преузет из једног од два речника синонима, уз њега се даје тачан податак о извору.
} 
на скривена [...] литература се појављује као примарна сила (ЕКор); Јер она очигледно приморава душу да се у тражењу истине служи мишљењем (ЕКор)). Тај ЕНТИтет БОРАвИ у нама (пр. На мени видите, како се човјек осјећа уздигнут изнад свих патюа, ако у његовом сриу столује истина и крепост (РСАНУ); Истину ћеш ти тек морати наћи у себи (РМС); Ушла је у њега та истина (ЕКор)). Са друге пак стране, иСтиНА може бити ЕНТИТЕТ КОЈИ ЈЕ ИЗВАН НАС. У том случају, СтРемИмо Јол (пр. То је ваљда оно што подразумевате под егзактном тежюом за истином (ЕКор); А толико у њеном неминовном приближавању истини (ЕКор); Они који трагају за истином више су од пријатеља (ЕКор)).

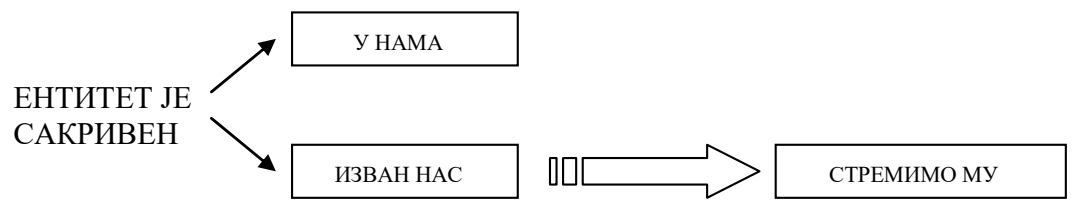

4.1.2. ИСТИНА JE ЕНТИТЕТ кОJЕ СЕ КРЕћЕ, а то кретање може бити (а) вертикално или (б) хоризонтално.

a) У вертикаЛном кретањУ, ИСТИНА ЈЕ ЕНТИТЕТ КОЈИ ТЕЖИ ДА ИЗБИЈЕ НА ПОВРшину (пр. ...[да ће] хришћанска истина увек бити некако потискивана (ЕКор); ...на повриину испливава истина, некоме на радост, некоме на јед (ЕКор)). Имајући у виду вертикалну димензију, ${ }^{7}$ истинА ЈЕ долЕ/дуБоко/дУБокА (пр. Само обиље води јасноћи, а у понору пребива истина (ЕКор); У тој формули из туристичког приручника крије се једна врло дубока истина (ЕКор)), а супротна крајња инстанца у тој вертикалној димензији подразумева другу оријентациону метафору (Лејкоф и Џонсон 1980: 14-19): истинА ЈЕ ГОРЕ, односно ПРОСТОР ИСТИНЕ JЕ ПРОСТОР НЕБА, Па ОТУДа ИСТИНА ЈЕ У БОЖЈОЈ СРЕДИНИ - ОНА ЈЕ У БОЖЈОЈ ВЛАСТИ И доЛАЗИ НАм од БОГА (пр. Та прича није лажна, то је богом дана истина (ЕКор); божанска истина (ЕКор)).

Она се, надаље, концептуализује и као равна повРшина која је у БожЈол СРЕдини, на шта нарочито указује употреба предлога на и његово типично значење засновано на односу ношењА (Кликовац 2018: 113-128) (пр. изр. испратити богу на истину (РСАНУ, РСЈ) ${ }^{8}$; На смрти дозва сина те ће му рећи: „Ја морам ићи драгоме алаху на истинак..." (РСАНУ)).

Поједини примери указују и на концептуализацију истинЕ кАО БогА (пр. бог је истина (ЕКор), уп. стих Сан је лажа, а Бог је истина), па у истину ВЕ-

\footnotetext{
${ }^{7}$ О појму вертикалне димензије као изворном домену в. Расулић 2004.

${ }^{8}$ Из културолошког аспекта гледано, изрази који означавају „додир са оним светом”, односно „умрети”: отићи богу на истину, послати (кога) богу на истину, бити на истини и сл. мотивисани су веровањем да је смртни час (умирање) час у коме се види истина, као божја тајна. „Она се у хришћанској филозофији (религији) доживљава као виђење светлости и представља суочење човекове бесмртне душе са богом, својим прапочелом" (Мршевић-Радовић 2008б: 185). О вези истине и светлости биће речи касније, у оквиру наших појмовних метафора.
} 
РУЈЕМО ИЛИ НЕ ВЕРУЈЕМо (пр. изр. веровати у истину (РМС); ујак је увек веровао у истинитост те изреке (ЕКор)). Синоними придева истинит такође потврђују ову метафору: поуздан (особина онога у кога се или у шта се може поуздати = веровати), веродостојан (особина онога што је достојно поверења), сигуран (чему се може веровати без икакве сумње), несумьив (поуздан, у шта се не може сумњати) (Лалевић 2004), као и синоним именице истинитост: веродостојност (Ћосић и др. 2007).

б) У хоризонталном кретању издваја се метафорички сценарио истинА JE ЕНТИТЕТ КОЈИ ЈЕ НА НАШЕМ ПУТУ, ИСПРЕД НАС ЈЕ, А МИ ИДЕМО ЗА ЊОМ (Пр. $\underline{y}$ mоj трии неминовно се приближавала истини која јој је увек предњачила (ЕКор)). ИСТИНА МОЖЕ БИТИ БЛИЗУ ИЛИ ДАЛЕКО (Све је то далеко од праве истине (ЕКор); истина тако дуго узалуд била пред юим (ЕКор)).

4.1.3. Наведена општа појмовна метафора истинА ЈЕ ЕНТитЕТ даље се може конкретизовати у виду појмовних метафора које се налазе ниже на скали конкретност-аПстрактност. ИстИНА ЈЕ: а) ЖИВО БИЋЕ; б) МАТЕРИЈА; в) ПРЕДМЕТ.

а) Појмовна метафора ИстИНА ЈЕ жИво БИЋЕ (пр. истовремено се постиже да се роди ум и истина (ЕКор)) конкретизује се даље у виду метафора: истинА ЈЕ осоБА 9 (пр. Нажалост, истина је скоро увек неоштроумна (ЕКор); Ти си само трећина правог човјека, треба погледати истини у очи. (РСАНУ)); и још конкретније - истИНА ЈЕ воЂА (Ако предводи истина, мислим да нећемо рећи како юу прати скуп порока (ЕКор)) или господАР (Кажете да не можете видјети владавине добра и истине на земљи (РСАНУ); ...али и служење истини јесте немало ограничење за приповедање (ЕКор)); истИНА ЈЕ ЖИвОТИњА (Истина навали на юу; како је уопште могла говорити, како је чак могла дисати, чудила се (ЕКор)); истИНА ЈЕ БИљКА (...та је истина тако дубоко укорењена у свести суседних породииа (ЕКор); истина у сазревању (ЕКор)).

б) Велики број примера из корпуса показује да се истинА концептуализује и као МАТЕРИЈА (пр. ...да му у том часу сручи истину у лице (ЕКор); Нема ни трунке истине у ономе што сам рекао (ЕКор)). И у оквиру ове метафоре може се Уочити Неколико конкретнијих - иСтИНА JЕ ТЕРЕТ (пр. Својим сународницима је говорио покашто тешке истине о богатству (ЕКор)) и истинА може бити ХЛАДНА или вРУЋА (пр. Оно што је Сузана рекла загрејана препирком стварно је било хладна истина (ЕКор); Сазнали су врућу истину. (ЕКор)). Неочекивану контрадикторну представу истинЕ која је хлАднА или вРуЋА могуће је објаснити на два начина: први начин подразумева да је хлАдно инхерентно својство истиHE, а вруЋЕ више подразумева поглед на истину са аспекта реакције других на њу; према другом објашњењу, хЛАДНА ИСТИНА ЈЕ ОГОљЕНА, док је вРУЋА она која је до пре неколико тренутака БИЛА ПОКРИвЕНА.

${ }^{9}$ На основу појединих твореница можемо видети и да је истиНА ОсоБА (ЕНтитЕТ) кОЈА/И СЕ воли: истинољуб, истинољубаи, истинољубив, истинољубиво, истинољубитељ, истинољубље, истинољубност (РСАНУ). Ове лексеме означавају особу која воли истину, која обавља нешто с љубављу према истини, те саму љубав према истини. У питању је служење истини и њено уздизање на пиједесталу моралних категорија. УП. иСтИНА ЈЕ гОСПОДАР (КОМЕ СЕ ПОКОРАВАмо). 
У конкретнијој представи ИСТИНЕ показује се да је она ХРАНљИВА МАТЕРИЈА НЕПРИЈАТНОГ УКУСА (Пр. Из њених уста и нека непријатна истина не би била гор$\underline{\kappa a}$ (ЕКор); Увек је истина о рођеној земли нешто што нам је неукусно (ЕКор); Јер је то сушта истина, која може да буде одвратна, непријатна (ЕКор)). На ИСТИНУ која је ХРАНљИВА МАТЕРИЈА УПућује и један од синонима истинитости у Ћосићевом речнику - незачињеност. Не тако малобројни примери показују да је истИНА БИСтрА течност, која је и наша ПотреБА (пр. Неће се одбити, ако им се улије у свест наша класна истина (ЕКор); Истина је прозрачна и не опажа се, а лаж непрозирна, не пропушта светлост ни поглед (ЕКор); Његова потреба за истином постајала је неутољива жеђ (ЕКор)), а понекад је и лЕк (пр. Односе између БиХ и СР Југославије може излечити једино истина (ЕКор)).

в) У корпусу се издвајају примери који показују да се истинА разуме и као ПРЕДМЕТ (пр. Клеветнички изврћу истину (РМС); ...верујете да тиме држите истину чврсто у својим рукама (ЕКор)), који се чврсто може држати, скупити, превртати, извртати (има спољашњост и унутрашњост) и који има јасне границе. Као предмет, она може бити СТАРА иЛИ НОВА, ВЕЛИКА иЛИ МАЛА (пр. $\underline{\text { Cmapa }}$ истина не смета никоме; нова свакоме (ЕКор); ...понављање офуцаних истина о љубави, животу и смрти (ЕКор); Мало-помало, од шала би истина крупна: Нола поста редак човек (ЕКор)). Деминутив/хипокористик истиница, истиничица указују на истину која је мАЛА (пр. Не трпи ни најмању истинииу (РСАНУ)), а лексикализовани аугментатив у речницима не постоји.

Када апстрактни појам разумемо као ПРЕдмЕт, то олакшава упућивање на њега, груписање, квантификацију. Отуда је истина бројива (пр. ...када би се саставиле све три приче, тако би се добила једна истина (ЕКор); ...сваки [драги] камен изражава више истина (ЕКор)). Истовремено, ИСТИНА ЈЕ ПРЕДМЕТ КОЈИ ПОСЕДУЈЕмо (пр. нама су одузели истину, нама! (ЕКор), Све је то моја лична истина (ЕКор); Ако ја умрем, истина ће бити заувек изгубљена (ЕКор)). Тај ПРЕДМЕТ УВЕК ИМА ИСТИ ЛИК (пр. Истина је једна (ЕКор); Кнезови народни веровали су Мустаји паши; јер све што им је он казао била је непритворна суuта и итина (РСАНУ) $)^{10}$ ИЛИ МОЖЕ СЕ САСТОЈАТИ ИЗ ДЕЛОВА (Пр. испричала сам јој само део истине (ЕКор); ...одговорио сам - рекли сте половину истине (ЕКор); Како се усудио рећи само један веома малени делић истине (ЕКор)). ИСТИНА ЈЕ ПРЕДМЕТ КОЈИ ИМА УНУТРАШњОСТ (Пр. Истина није тако потпуна у свом изразу, она се не испољи сва, юу треба загледати изнутра (ЕКор); ...да дефинишем њоме празнину истине (ЕКор)). Тај ПРЕДМЕТ МОЖЕ ДА ПОВРЕДИ (Пр. Тибинг осети како се истина хладно и болно сручује на њега (ЕКор); ...како би лакше поднела удар кад се открије истина (ЕКор); Истина му се забила у срие таквом снагом да се затетурао уназад (ЕКор)), па отуда истину зАоБилАзимо (пр. Истина је само једна, од юе се бежи многим друмовима (ЕКор); изр. заобилазити/обилазити истину, околишати око истине (РСАНУ; РМС; РСЈ)). Због свог деструктивног

\footnotetext{
${ }^{10}$ Исп. и синониме: неизмењеност, изворност, непатвореност (Ћосић и др. 2007).
} 
дејства, истинА ИзАзивА СтРАх (пр. Али зар то није стравична истина? (ЕКор); Бојим се да је то истина (ЕКор)).

У контексту ИСТИНЕ која ЈЕ ПРЕДМЕТ, издваја се појмовна метафора ИСТИНА ЈЕ ГРАЂЕВИНА (пр. ... у покушајима изграђивања биолошке истине (РСАНУ); Госпођо, то је необорива истина. (ЕКор)). И поједини синоними представљају истину као гРАЂЕвину или твРЂАву. Тако ће М. Лалевић навести синоним за придев истинит - неосвојив, уз објашњење ,у овом смислу има апстрактније значење - казује особину онога што се не може освојити, одузети, уништити" (2004: 233). Исти аутор ће за истинитост понудити синоним основаност, који објашњава као „разложност која се заснива на чврстим темељима истине, непобитности; основаност суђења, мишљења, закључака" (2004; курзив је наш - В. И.). У Речнику синонима П. Ћосића (2007) као синоними за истинитост наводе се, између осталих, и: сигурност, необоривост.

На опредмећеност истинЕ указује и нешто конкретнија појмовна метафора ИСТИНА ЈЕ РОБА КОЈА ИМА ЦЕНУ (Пр. ... то је доставио невидљив човек, чија је истина била јевтинија од лажи (ЕКор); ...оне суме патьи која је била неопходна да се плати та истина (ЕКор)).

4.1.4. Најзад, последњи скуп метафора тиче се односа САДРжАВАњА. Примери из корПУса ПоКазујУ да ИСТИНА МОЖе бИТИ И САДРЖАТЕЉ, И САДРЖАНИ ОБЈЕКАТ (СО) У САДРЖАТЕЉУ.

1) КАО САДРЖАТЕЉ, ИСТИНА ОКРУЖУЈЕ ЧОВЕКА (Пр. Треба Умрети у истини. (ЕКор); Софки се не поче да чини, него је већ као у истини осећала како све то није оно, у ствари. (ЕКор)).

2) Са друге стране, ИСТИНА ЈЕ САДРЖАНИ ОБЈЕКАТ У САДРЖАТЕљУ (Пр. [Појмови] обухватају својим садржајем множину геометријских факата и истина (РСАНУ); То није анализирање света како би се из юега извукла истина мале вероватноће (ЕКор); ...истина коју препознајем у патьи (ЕКор); Истина је $у$ љубави (ЕКор); Је ли истина оно ито у њој [књизи] пише? (ЕКор); Истина је у човеку, изнутра (ЕКор); Препирке су пуне истине и озбиљности (ЕКор)). Наведени примери показују да садржатељи могу бити различитог типа. То су: појмови, особе, осећања, књиге, препирке.

Посебно се издвајају случајеви када су САДРЖАТЕљИ ЗА ИСТИНУ језичке једиНИЦе: РЕЧ, ЗАВИСНА РЕЧЕНИЦА, ОДНОСНО ИСКАЗ:

a) САДРЖАТЕЉ ЈЕ РЕЧ [ИстИНа], ИСТИНА САДРЖАНИ ОБЈЕКАТ, ШТО ПОТВрђУјУ следећи примери: ...већ им се истина сасвим слободно може рећи у лище (ЕКор); ...nошто вам казујем истину (ЕКор); То је очигледна истина коју би било сувише понављати (ЕКор). Поједине творенице из РСАНУ такође потврђују исту метафору: истинословац, истинословчев („онај који говори истину”). Наведени начин концептуализације једноставно се објашњава на основу односа ознаке и означеног У језикУ, који се Може КОНЦеПТУаЛИЗОВаТИ Као ОЗНАКА ЈЕ САДРЖАТЕЉ ЗА ОЗНАЧЕНО, иЛИ КаКо Д. КЛИКовац НаводИ На јеДНОм МестУ, ЈЕЗИЧКА ЈЕДИНИЦА ЈЕ САДРЖАТЕЉ ЗА ЗНАЧЕњЕ (2000: 187). У Нашем сЛУЧајУ, „ИстИНа” је ОЗНАКА, а ОЗНА- 
ЧЕНО - СТВАРНОСТ, Па отУда би наведена метафора МогЛа Да ГЛаси РЕЧ ИСТИНА ЈЕ САДРЖАТЕЉ ЗА СТВАРНОСТ.

б) У следећем кораку у оквиру самог исказа експлицира се садржина речи „истина”. Дакле, изриче се ванјезичка стварност на коју се ова реч односи, тј. као да се сада садржина „истине” прелива у шири садржатељ - исказ. Па отуда исКАЗ ЈЕ САДРЖАТЕЉ, ИСТИНА САДРЖАНИ ОБЈЕКАТ, ШТО ПОКаЗУјУ ПрИМерИ: Је ли истина да се у Паризу непрестано смеју? (ЕКор); Истина је да сам ја у сродству са полубратом Његовог иарског величанства (ЕКор); Могао је говорити што је хтео, то је истина (ЕКор). ${ }^{11}$

У великом броју примера истинА је у речи, реченици или њеном делу - било у усменом или писаном језику. Стиче се утисак да се на тај начин истинА - као апстрактни појам - „пакује” и укалупљава у језичку јединицу, која је садржалац за поменути апстрактум. Ни сама реч или реченица не представља типичан конкретни појам, али је бар за степен ниже од истинЕ на скали конкретност-апстрактност, будући да се у усменом дискурсу реализује кроз звук (линеарно кроз време), а у писаном линеарно кроз простор, при чему њену експлицирану, вербализовану садржину можемо подвући и указати на њу конкретно.

4.1.5. Са последњом наведеном метафором, која илуструје однос САдРжАВАњА, представили смо све метафоре чија је најопштија ИстиНА ЈЕ ЕНТИТЕт. Остаје нам да представимо део грађе који показује разумевање истинЕ као поЈАВЕ.

4.1.6. Као и већина физичких појава које нас окружују, истинА ЈЕ поЈАВА КОЈА СЕ ОСЕЋА (пр. Ако је истина непријатна, утолико горе (ЕКор); Целог сам живота осећао да није истина! (ЕКор); Понекад имамо нејасно осећање истине (ЕКор)). ТА ПОЈАВА СЕ МОЖЕ СПОЗНАВАТИ (Пр. Само ако спознамо истину те радикалне истоветности (ЕКор); Тако и по ту ичену о стварима дознавали истину (ЕКор); Његово схватање истинитости много се разликује од схватања која имају неки ращионалисти (Лалевић 2004)). Као таква, мерљива је физичком величином времена, односно има неограничено трајање, па кажемо истинА ЈЕ ВЕчНА ( регион вечитих истина (ЕКор)).

a) Наредна појмовна метафора показује да се истинА концептуализује као конкретна физичка појава - истинА ЈЕ Светлост ${ }^{12}$ (ПР. Ако се она усмери према предметима које обасјава истина (ЕКор); ... коју зари само велика и непобитна истина (ЕКор); Истина блиста од своје сопствене очигледности (ЕКор); ... чија му је дубока истина осветлила книжевнички живот (ЕКор)).

б) Други вид конкретизације истинЕ као ФизичкЕ пОЈАВЕ представља метафора ИСтинА ЈЕ СИЛА (пр. Толика је снага истине која се, као и добро, сама од себе распростире (ЕКор); ...ми смо са страхом, додуше, али присиљени истином

${ }^{11}$ У нашем корпусу највише је оваквих примера.

${ }^{12}$ Светлосни аспект истине веома је важан и у лингвокултуролошком погледу: истина се ту везује за праведног Бога. Само сунце представља Божје око, у које се не може широм отворених очију гледати, као ни у истину саму. Самртни час, у којем се суочавамо са божанском истином, у хришћанском учењу се доживљава као виђење светлости (исп. Мршевић-Радовић 2008б: 185). 
рекли да ниједна држава... (ЕКор); Истина је убила нашу наду (Лалевић 2004); Ал' истина је напокон пробила пут. (РМС)).

4.2. ИСТИНА у Асоцијативном и Обратном асоцијативном речнику српског језика. Преостаје нам да испитамо речи-реакције на стимулус истина у Асоцијативном речнику српског језика, односно да на основу Обратног асоцијативног речника утврдимо на које је речи-дражи истина била реч-реакција, те да на тај начин дођемо до појмовних метафора које се крију у асоцијацијама колектива. Очекивали бисмо извесну подударност са оним метафорама које су потврђене анализом првог дела корпуса.

Наведене асоцијације уз стимулус истина из Асочијативног речника поделићемо у три групе. У првој групи налазе се најфреквентније (првих пет), у другој су нешто мање фреквентне, а у трећој групи су неке од најмање фреквентних асоцијација.

I лаж (291), правда (47), боли (21), искреност (19), Бог, поверење (11);

II бол, суд, врлина; неистина, тачно, тачност; поштене, стварност; доброта, једина, реткост, вредност; чиста, је тамо негде, лепота, љубав, недостижно, помирење, права, увек;

III болна, чињеница, чистоћа, добро, тешка, велика, закон; чисто, далеко, филозофија, гола, искрен, историја, једна.

Најважније су реакције из прве групе, односно речи које су испитаницима прве падале на памет. Најчешћа реакција на истину јесте њен антоним лаж, што говори у прилог тврђењу да се ради о правим антонимима (претпоставља се да су они у најтешњој вези у менталном лексикону, те на подстицај једног члана антонимског пара, прво што пада на памет јесте други члан). Следи реакција правда, која је синоним истини. Наиме, било је речи о истини као Богу, а његово деловање на Земљи огледа се у спровођењу правде. Метафоре истинА JЕ У ВЛАСТИ БОГА И ИСТИНА ЈЕ БОГ огЛедају се и У реакцијама Бог, одн. поверење - У иСТИНУ вЕРУЈЕмо (тј. особи која је говори). Потом, трећа по реду је реакција боли, која је у складу са метафором ИСтИНА (ЈЕ ПРЕДМЕТ КОЈИ) МОЖЕ ДА ПОВРЕДИ. Најзад, искреност, као четврта реакција на стимулус истина, у вези је са метафОРОМ ИСТИНА ЈЕ САДРЖАНИ ОБЈЕКАТ (СО) У ИСКАЗУ, КОјОј ДОДајеМО: КОЈИ ГОВОРЕ ИСКРЕНЕ ОСОБЕ.

На основу прегледа најфреквентнијих асоцијација, показује се типичан сцеНарИО: ИСТИНА ПОТИЧЕ ОД БОГА, КОЈИ НА ЗЕМљИ СПРОВОДИ ПРАВДУ. НЕКАДА СЕ НЕРАДО СУОЧАВАМО СА ЊОМ ЈЕР МОЖЕ БИТИ БОЛНА. АКО ЈЕ ПРЕНОСИМО ДРУГИМА, ТО ЧИНИМО ПОМОЋУ ИСКАЗА. КО ГОВОРИ ТАКАВ ИСКАЗ, ИСКРЕН ЈЕ.

Примери из друге и треће групе допуњују наведени метафорички сценарио метафорама које су већ потврђене анализом већег дела корпуса. истинА ЈЕ ЈЕДНА, ОДГОВАРА СТВАРНОСТИ И ДАЛЕКА ЈЕ. ОНА ЈЕ ПРЕДМЕТ (реткост, вредност, веЛИКа, ТеШКа) КОЈИ МОЖЕ ДА ПОВРЕДИ. ИСТИНА ЈЕ И САДРЖАНИ ОБЈЕКАТ У ИСКАЗУ (бол, суд, тачно, тачност, поштене, помирење). 
Обратни асоцијативни речник показује да је истина најчешћа реакција на стимулусе - лаж (192), у вину (97), суочавање (73), рећи (37), трач (36), лагати (27), праведан (17), истински (10). И овде је назначена чврста веза са лажи у менталном лексикону, будући да је истина најфреквентнија реакција на ову именицу. Интересантан је податак о стимулусу у вину, на који се истина чак 97 пута јавила као одговор, изазван широко познатом изреком $У$ вину је истина, која ПОТврђУје метафорУ ИСТИНА ЈЕ СО У САДРЖАТЕЉУ. ПрИ ТОМе, САДРЖАТЕљ је ВИНО, али и, метонимијски, чОВеК КОЈИ ПИЈЕ вино. Истина излази на видело када се оно (по)пије, па отуда: истинА ЈЕ у НАмА. Наш корпус није показао ниједан други пример који доводи у везу истину и вино, осим овог идиосинкратичког, а опет веома познатог примера. Веза суочавања и истине потврђује метафору истиНА МОЖЕ ДА ПОВРЕДИ, док стимуЛуси рећи и трач указују на метафору ИСТИНА JE (СО) у искАЗУ. Лагати је у некој врсти антонимске везе, истински - у творбеној, а праведни је у вези са њеним синонимом и потврђује наведене метафоре БОЖАНСКА ИСТИНА ЈЕ ПРАВДА НА ЗЕМЉИ. КО ГОВОРИ ИСТИНУ, ПРАВЕДАН ЈЕ.

\section{5. Закључак о концепту истинЕ у савременом српском језику}

Концептуална анализа примера из представљеног корпуса показала је да се истина у српском језику на генеричком нивоу концептуализације разуме као 1) ЕНТИТЕТ илИ као 2) ПОЈАВА.

(1) У слУчајУ ЕНТИТЕТА, она је тиПично САКРИВЕНА; Може бИТИ У НАМА иЛИ ИЗВАН НАС. Када је изван Нас, МИ ЈОЈ СТРЕМИМО. Истина је ЕНТИТЕТ КОЈИ СЕ КРЕЋЕ у вертикалном или хоризонталном смеру. Крајње инстанце вертикалне димензије означене су оријентационим метафорама ИСТИНА ЈЕ ДОЛЕ И ИСТИНА ЈЕ ГОРЕ. Када је доле, истинА у вертикалном кретању тЕЖи дА изБИЈЕ НА ПОвРшину. Када је ГОре, ОНА ЈЕ У ВЛАСТИ БОГА ИЛИ БОГ САิМ, ТО У ФУ ВЕРУЈЕМО ИЛИ НЕ ВЕРУЈЕМО. На земљи се реализује у виду БОжЈЕ ПРАВДЕ. У хоризонталном кретању она идЕ ИСПРЕД НАС, А МИ ЈЕ СУСТИЖЕМО.

(1.1) Даља конкретизација ЕНтитЕТА упућује да истинА може бити живо БИЋЕ, МАТЕРИЈА ИЛИ ПРЕДМЕТ. КаО ЖИВО БИЋЕ, ИСТИНА је ЧОВЕК/ОСОБА, БИљКА ИЛИ животињА. У првом случају, као осоБА, може се даље конкретизовати као воъА ИЛИ ГОСПОДАР. ВИђеНа КаО МАТЕРИЈА, ИСТИНА ИМа ТЕЖИНУ (ОНА ЈЕ ТЕРЕТ) И ТОПЛОТУ (ХЛАДНА ИЛИ ВРУЋА), ХРАНЉИВА ЈЕ, аЛИ НЕПРИЈАТНОГ УКУСА, ТЕЧНА И БИСТРА. Схваћена као пРЕДМЕТ, описују је следеће карактеристике предметности: старост, величина, припадање, (не)дељивост. Тај предмет моЖЕ ДА повРЕДИ, ТЕ ГА ЗАОБИЛАЗИМО. Са друге стране, она је тиПичНо стамена ГРАЂЕВИНА, а У ширем СМИСЛУ САДРЖАТЕЉ. МОЖе бИТИ И САДРЖАНИ ОБЈЕКАТ - У РЕЧИ ИЛИ ИСКАЗУ.

(2) ИСТИНА JЕ И ФИЗИЧКА ПОЈАВА, будући да је карактерише време/трајање

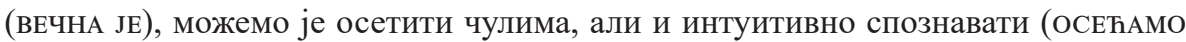
JЕ) и ИсПИТИВаТИ је (МОЖЕМО ЈЕ САЗНАВАТИ И ПРОУЧАВАТИ). На НИЖем НИВоУ аПстракције типично се концептуализује као СвЕтЛост или СИЛА. 
Преостаје да у следећем раду представимо концепт лАжи као други део овог истраживања и, ослањајући се на концепт истине, укажемо на основне сличности и разлике међу њима, те да у закључку одговоримо на она питања која су се наметнула пре анализе представљеног корпуса.

\section{ЛИТЕРАТУРА}

Буслајев 21867: Фёдор Буслаев, O преподовании отечественнаго языка, Москва: Издание братьевъ Салаевыхъ.

Ван Дитмарх и др. 2020: Hans van Ditmarsch, Petra Hendriks, Rineke Verbrugge, „Editors' Review and Introduction: Lying in Logic, Language, and Cognition”, Topics in Cognitive Science, 12 (2020), p. 466-484.

Гентнер и Баудл 2008: Dedre Gentner and Brian Bowdle, „Metaphor as Structure-Mapping", in: The Cambridge Handbook of Metaphor and Thought (ed. by Raymond W. Gibbs, jr.), Cambridge: Cambridge University Press, p. 109-128.

Драгићевић 2010: Рајна Драгићевић, Лексикологија српског језика, Београд: Завод за уџбенике.

Еванс и Грин 2006: Vyvyan Evans and Melanie Green, Cognitive Linguistics: An Introduction, Edinburgh: Edinburgh University Press.

Кевечеш 22010: Zoltán Kövecses, Metaphor: A Practical Introduction, New York: Oxford University Press.

Кликовац 2000: Duška Klikovac, Semantika predloga, studija iz kognitivne lingvistike, Beograd: Filološki fakultet.

Кликовац 2004: Duška Klikovac, Metafore u mišljenju i jeziku, Beograd: Biblioteka XX vek.

Кликовац 2018: Душка Кликовац, Српски језик у светлу когнитивне лингвистике, Београд: Друштво за српски језик и књижевност Србије.

Лејкоф и Џонсон 1980: George Lakeoff and Mark Johnson, Metaphors We Live By, Chicago - London: The University of Chicago Press.

Лејкоф и Џонсон 1999: George Lakeoff and Mark Johnson, „The anatomy of complex metaphor", in: Philosophy in the Flesh. The Embodied Mind and Its Challenge to Western Thought, New York: Basic Books, p. 60-73.

Мршевић-Радовић 2008а: Драгана Мршевић-Радовић, „О антропоцентризму у српској фразеологији (,,лажљив”, „лагати” у синхронији и дијахронији)", Кюижевност и језик, LV: 1-2, стр. 47-56.

Мршевић-Радовић 2008б: Драгана Мршевић-Радовић, Фразеологија и национална култура, Београд: Друштво за српски језик и књижевност Србије. 
Ортега и Гасет 2010: Hose Ortega i Gaset, „Dve velike metafore”, Mostovi, 38/147, sv. 1, str. 212-222.

Расулић 2004: Katarina Rasulić, Jezik i prostorno iskustvo: konceptualizacija vertikalne dimenzije u engleskom i srpskohrvatskom jeziku, Beograd: Filološki fakultet.

Свитсер 1990: Eve Sweetser, From Etymology to Pragmatics. Metaphorical and Cultural Aspects of Semantic Structure, Cambridge: CUP.

Слијепчевић и Новокмет 2012: Светлана Слијепчевић и Слободан Новокмет, „О концептуализацији појмова истина и лаж у српском језику од 19. до 21. века", у: Време и история в славянските езици, литератури и култури, сборник с доклади от Единадесетите национални славистични четения, 19-21 април 2012, Том I, Езикознание (съст. Бурова, А. и др.), София: Университетско издателство „Свети Климент Охридски”, 165-173.

Станишић 2012: Вања Станишић, „О северним индоевропским везама албанског језика", у: Praslovanska dialektizacija v luči etimoloških raziskav, Ob stoti obletnici rojstva akademika Franceta Bezlaja (ur. Furlan, M., Šivic-Dular, A.), Ljubljana: Inštitut za slovenski jezik Frana Ramovša ZRC, SAZU, 199-211.

Унгерер и Шмид 1996: Friedrich Ungerer and Hans-Jörg Schmid, An Introduction To Cognitive Linguistics, Edinburgh Gate, Harlow: Longman.

Черњејко 1997: Людмила Олеговна Чернейко, Лингво-философский анализ абстрактного имени, Москва: Филологический факультет.

Шкембер 2012: Ante Škember, „Istina u filozofiji i objavi. Poimanje istine u filozofiji i kršćanstvu", Nova prisutnost, 10/1, str. 105-113.

\section{ИЗВОРИ}

Драгићевић и др. 2011: Рајна Драгићевић, Предраг Пипер, Марија Стефановић, Обратни асоцијативни речник српскога језика. Део 2, Од реакције ка стимулусу, Београд: Београдска књига.

EКор: http://www.korpus.matf.bg.ac.rs, Korpus savremenog srpskog jezika, Matematički fakultet Univerziteta u Beogradu.

ЕССЯ 1974-: Этимологический словарь славянских языков: праславянский лексический фонд, Институт русского языка РАН, Москва: Наука.

Лалевић 2004: Miodrag S. Lalević, Sinonimi i srodne reči srpskohrvatskoga jezika, Beograd: Nolit.

OEP: https://www.etymonline.com, Online Etymology Dictionary [of Modern English].

Пипер и др. 2005: Предраг Пипер, Рајна Драгићевић, Марија Стефановић, Асоцијативни речник српскога језика. Део 1, Од стимулуса ка реакцији, Београд: Београдска књига.

PMC I-VI: Речник српскохрватскога књижевног језика, Нови Сад: Матица српска, 1967-1976.

PCАНУ I-XXI: Речник српскохрватског књижевног и народног језика, књ. VIII и XI, Београд: Институт за српски језик САНУ, 1959-. 
PCJ: Речник српскога језика, Нови Сад: Матица српска, 2007.

Скок 1971-1974: Petar Skok, Etimologijski rječnik hrvatskoga ili srpskoga jezika, I, II, IV, Zagreb: JAZU.

Ћосић и др. 2007: Павле Ћосић и сарадници, Речник синонима и тезаурус српског језика, Београд: Корнет.

Валентина М. Илич

\section{АБСТРАКТНЫЕ ИМЕНА ИСТИНА И ЛОЖЬ В СОВРЕМЕННОМ СЕРБСКОМ ЯЗЫКЕ: КОНЦЕПТУАЛИЗАЦИЯ ИСТИНЫ}

(когнитивно-лингвистический подход)

Резюме

Эта статья представляет первую часть исследования в котором был проведен анализ абстрактных существительных имен истина и ложь, с точки зрения когнитивной лингвистики, на базе современного сербского языка, т.е. методом концептуального анализа. В самом начале объяснена природа абстрактных существительных, а затем представлены их этимология и современная семантика. Основная часть статьи - концепт истины, представлен концептуальными метафорами, сгруппированными на различных уровнях общности. В самом конце делается вывод и выделяются ключевые характеристики формирования этого понятия в нашей когнитивной системе. В следующей статье будет представлена вторая часть исследования - концепт лжи и будет сделан вывод об общих чертах концептов этих антонимов.

Ключевые слова: истинА, ложь, абстрактное имя, когнитивная лингвистика, концептуальный анализ, концептуальная метафора, концепт. 